\title{
Globalization and Its Effect on the Novels Translated into Persian: A Postcolonial Approach
}

\author{
Niloufar Fallahshahrak \\ Department of English, East Azarbaijan Science and Research Branch, Islamic Azad University of Tabriz, Iran \\ Bahloul Salmani \\ Department of English, East Azarbaijan Science and Research Branch, Islamic Azad University of Tabriz, Iran
}

\begin{abstract}
Translation can be considered as one of the ways which make different cultures closer to each other. Sometimes this affinity can make cultures to adopt some cultural elements. Cronin (2003) named this phenomenon "globalization". This becomes an important issue when it comes to dominant and dominated cultures. This study was intended (1) to show how globalization can affect translations of Persian novels and (2) to show what strategies the translators use, in order to see if translation and globalization serve English language and impose Western culture into dominated culture, or help dominated cultures to become globally known. "Domestication" and "foreignization" strategies introduced by Venuti (1995) have been considered as main framework of this study. In order to analyze the effects of globalization, culture-specific items have been chosen as the unit of the study. The corpus of the study was an American novel entitled, The New York Trilogy, written by Paul Auster and its Persian translation by Khojaste Keyhan and Shahrzad Lolachi. The analysis revealed that although foreignization strategy is more common; whenever an element is against Iran's religious or traditional rules, domestication strategy was preferred.
\end{abstract}

Index Terms - globalization, culture specific items, foreignization, domestication, postcolonial approach

\section{INTRODUCTION}

Translation plays a crucial role in globalizing the cultures in the world. Nowadays, people of the world share more cultural habits than before. Maybe someday everyone would have a homogeneous, globalized culture. However, right now everyone is living in societies where there are different cultures and the relationship between these cultures is asymmetrical. It seems a controversial situation living within the dominated and dominant cultures. According to Wang (2009) "if translations from dominated cultures construct an image of non-western cultures as inferior, creating a need and justification for western civilizing missions, translations from dominant cultures, much larger in quantity than those from dominated cultures, serve the very purpose of intellectual colonization" (p. 202). Wang (2009) also mentioned that "during the past two decades, postcolonial studies of translation have redefined our understanding of translation, particularly its relation to power, ideology and empire building" (p. 203).

As a result of globalization, English language is rapidly gaining strength. This can be seen in the direction and traffic of translation. Most, if not all of the translations are from English and not into it. This can be a reason for globalization. Thus, non-English societies import textual products made in English. However, they do not merely import texts, but cultures are imbedded within texts. In such situations, translators face a dilemma. S/he can either import the cultural element into the target language and culture, i.e. use foreignization strategy (Venuti 1995) or s/he can change the cultural element as an act of resistance against the powerful language and culture, i.e. English. Venuti (1995) called the latter domestication strategy. If globalization means a homogeneous culture, then foreignization serves this end. Most of the non-English and non-natives maybe know more about the western culture because of the huge range of the books translated from it. This can lead to globalization. This can be a unilateral globalization if the globalization of cultures is a western one. Foreignization can be the consequence of this kind of globalization. This fact can fade or even lead to the disappearance of the dominated cultures and even great losses in all non-English languages.

Literature has a great influence on the culture, and translations of literary texts are usually the main reason of the cultural changes. The translations of the literary texts deliver new ideas and cultural elements to the nations. Some cultures, being dominated are more ready for cultural changes. The translators of these countries may usually are considered as foreignized translators while the translators of dominant cultures usually prefer naturalness and fluency in translations. As an example, when Iranian translators translate the concepts like Halloween, Valentine, Christmas, etc. globalization can take place. So gradually the literature of the dominated cultures can get affected and so does the culture itself. As a result of globalization, English gets more powerful. Venuti (1992) says that English has become a source language. Most of the societies translate from English while English doesn't really want to translate from other languages. The problem is that by doing this, English gains more power and so does the English culture and gets the role of a colonizer; in this case the other cultures can be considered as colonized. This fact gives two choices to the translator while translating: s/he can choose to use foreignization strategy or domestication strategy. The first one can 
lead to the entrance of the cultural elements to the target language and culture, which means English language and culture would impose itself to the target language and culture. On the other hand, the latter prevents from the entrance of the cultural elements of the source language to the target language.

The present study is an attempt to investigate the cultural elements of the translated texts and to see that if globalization happens and if it does, to see what its effect is on the novels translated into Persian which would be studied and analyzed in this research from a postcolonial approach to investigate if translation is serving to the expansion of English language and culture or helps to dominated culture's expansion. For example when a Persian translator translated Valentine's Day and gave footnote for it, $\mathrm{s} /$ he may have had no idea that s/he is actually globalizing the western culture. Results would help to the practicing translator to get more familiar with the strategies of translation and do more theoretical translations. The results would let trainers and trainees to translate considering the effects that a translation can has on the culture of the target language in the first place and the faithfulness to the source language in the second place.

The purpose of this study is to see how important the role of the translators is, and that how they can play crucial roles in fading some cultural elements or how to make them more strong. The research was attempted to analyze some culture specific items of an English novel, The New York Trilogy, written by an American author, Paul Auster. Translations would help different cultures to get closer to each other and they also can give a better understanding of different cultures to everyone. Although during the process of translation some cultural elements may enter to the culture of target language. This study is expected to firstly analyze the cultural elements in the translation of novels and secondly to see how globalization took place on the translations from a postcolonial approach.

\section{LITERATURE REVIEW}

\section{A. What Is Culture?}

Goodenough (1964) has defined culture as consisting of "whatever one has to know or believes in order to operate in a manner acceptable to its members, and to do so in any role that they accept any one of themselves" (p. 167).

Sahlins (1995) defined culture as a "set of distinctive spiritual, material, intellectual and emotional features of society or a social group" (p. 3). In addition to art and literature, culture refers to concepts such as lifestyle, ways of living together, value systems, traditions and beliefs.

\section{B. Culture-specific Items}

According to O'Donoghue (2005), culture-specific terms are lexical and cognitive gaps. He pointed out that such terms originate from different ways of life, traditions, beliefs, and historical developments. He also maintained that these terms "refer to objects and concepts related to for example ecological, material, social, religious, and political features of a culture" (p. 10). As O'Donoghue (2005) pointed out, culture-specific terms are terms that refer to objects and concepts that relate to different aspects of culture and their culture-specificity depends on the languages involved and cultural distance between the ST and TT readers. These terms are lexical and cognitive gaps and the changes of cognitive meaning between culture-specific terms and their translations create interpretation problems for a TT reader (p. 11). He noted that "studies on culture-specific terms and their translations have shown that all translation procedures of culture-specific terms seem to manifest some changes of meaning" (p. 13).

Newmark (1988, p. 14, quoted in Terestyényi 2011) spoke of cultural words; he defined culture as the way of life and its manifestations that are peculiar to a community that uses a particular language as its means of expression, thereby acknowledging that each language group has its own culturally specific features. He classified cultural words as follows: 1) ecology: flora, fauna, hills, winds, plains; 2) material culture: food, clothes, houses and towns, transport; 3) social culture: work and leisure; 4) organizations, customs, activities, procedures, concepts: political and administrative, religious, artistic; and 5) gestures and habits.

\section{Globalization}

Since twentieth century, some "changes" have globally influenced and touched the everyday life of people from different aspects, i.e. "economics, cultures and societies". Cronin (2009) called these changes "globalization" (p. 126). According to him (2003, p. 77), the term globalization has "the sense of a critical theory of globalization that encompasses global movements and exchanges of people, commodities, and ideas, and a politico-historical approach to changes in global processes" (quoted in Ho 2005, p. 86). Cronin (2003) further distinguished between "instantaneous time" and "mnemonic time". Instantaneous time in translation refers to the time pressure that creates a situation "where space-time compression and time-to-market imperatives generate demands for an extremely rapid turnaround of translation job" (p. 71, quoted in Ho 2005, p. 87). Mnemonic time in translation, in contrast, is the time assigned to translation tasks that bring existing yet inaccessible texts created in ancient times or in another language and culture to the current society or the host culture that receive the texts form past or from after. Cronin (2003, p. 34) remarked that "within a context of multiple modernities it is more proper to talk not so much about translation and globalization as about globalization as translation". Rather, translation should be regarded as "a constituent, integral part" of globalization instead of "a by-product" of it. Cronin (2003, p. 34) stressed that globalization has facilitated the explosive demand for translation rather than the demise of translation as an activity. According to Cronin (2009) on the 
one hand, there is the centripetal form, the notion of globalization as homogenization. This implies imperialism, subjection, hegemony, Westernization or Americanization. On the other hand, there is the centrifugal form, suggesting globalization as resulting in interdependence, interpenetration, hybridity, syncretism, creolization and crossover (pp. 127-8).

According to Pieterse (1995, pp. 45-67), what is at stake in the relation between the phenomenon of globalization is a tension between the so-called centrifugal and centripetal forms of globalization (quoted in Cronin 2009, p. 127). Pieterse (1995) pointed to various conceptualizations of globalization, especially in cultural studies where the focus is on the global communications and worldwide cultural standardization (p. 45). According to Pieterse (1995), globalization emanate from Europe and West. Indeed, it is a theory of Westernization, which replicates all the problems associated with Eurocentrism. For him, it is a narrow window on the world, historically and culturally. Due to this reason, he called it Westernization and not globalization (pp. 46-7).

\section{Postcolonial Approach in Translation Studies}

According to Venuti (2004), during the1980s a postcolonial reflection on the translation in disciplines such as anthropology, area studies and literary theory and criticism emerged. For Venuti (1995a) "fluent, domesticating translations create the illusion of invisible translators and transparent representations, which helps to conceal their imperialistic, ethnocentric reduction of cultural difference" (quoted in Wang 2009, pp. 201-2). Venuti argued that translation tends to be an invisible practice in the United States and is judged successful when it reads 'fluently'; giving the appearance that it has not been translated (Gentzler, pp. 15-16). The problems with such a situation are twofold: (1) it marginalizes practicing translators making them subservient to the author and defining their practice as derivative and secondary; (2) it erases the linguistic and cultural differences of the foreign text that the very act of translation purports to carry over into the receiving culture (Gentzler, p. 16). For (1995a, p. 20) foreignizing translation was a means of resisting 'ethnocentrism and racism, cultural narcissism and imperialism' and promoting 'democratic geopolitical relations' (quoted in Wang 2009, p. 203).

Wang (2009) pointed out that if translations from dominated cultures create an image of nonwestern cultures as inferior and create a justification for Western agenda, the translations from dominant cultures serve the very purpose of intellectual colonization (p. 202). For Wang, translation is not merely a channel of colonization. It can also be a means of resistance to colonial and neocolonial powers. Some of the researches have revealed traces of resistance in translations undertaken in colonial contexts and proposed ways of putting translation at the service of decolonization (Wang 2009, p. 202).

\section{METHODOLOGY}

The type of this study is of interpretative approach which is of qualitative type. Roughly speaking, the goal of qualitative research is to describe the quality of something in some enlightening way. More strictly, qualitative research can lead to conclusions about what is possible, what can happen, or what can happen at least sometimes; it does not allow conclusions about what is probable, general or universal. (Williams \& Chesterman 2002, p. 64)

This research is going to be based on the ideas of scholars who already worked and researched about globalization and postcolonial approaches in translation. The foreignization and domestication model of Venuti (1995) would be the basic theoretical framework of the study in recognizing the results from a postcolonial approach. The unit of the study is culture-specific items (CSIs); the categorization of different scholars was based in identifying cultural elements, namely Newmark (1988) and O'Donoghue (2005). The research also followed the definition that Cronin (2003) presented on globalization.

The comparison was between a novel in English, New York Trilogy, by Paul Auster (2006) and the translation of the novel into Persian translated by Khojasteh Keyhan and Shahrzad Lolachi (2010).

In order to discover the cultural elements which have or may have globalization effects on the culture through a postcolonial approach, the source text of Paul Auster's, novel The New York Trilogy was compared by its translation.

Venuti (1995a) divided translations into domestication and foreignization types. This study tried to discover that which one is more common among translators and that if dominant culture imposed its cultural elements into dominated culture. This study also intended to see that what effects globalization had on dominated culture of Iran and that if translation leaded to the entrance of the cultural elements of dominant culture into dominated culture or not. In order to do so, the researcher first analyzed the cultural specific items from globalization view. On the next aspect cultural items has been analyzed from postcolonial aspect and at the end a chart has been illustrated to show that if translators preferred domestication or foreignization on their translations.

\section{ANALYSIS}

In this section a small number of culture-specific items (CSIs), which have been taken from The New York Trilogy novel, has been taken in order to illustrate and analyze the translation of CSIs from a globalization aspect and also from a postcolonial view.

تتها سرخ بوست خوب سرخ بوست مرده است.

(Lolachi and Keyhan 2010, p. 64) 
The only good Indian was a dead Indian (Auster 2006, p. 42).

Romanization of the Sample:

tanhā surkhpūst-i khūb surkhpūst-i murdah ast.

\section{A. Culture-specific Item(s)}

This is an old American saying. Pilgrims who were colonizer Europeans migrated to the America. Early Americans killed a lot of native Indians, native people of the North America, while they first arrived to the America and put the rest on reservations.

This saying wants to show that no Indian is good. As Auster (2006, p. 42) wrote in his novel "it was not until 1537, with the papal bull of Paul III, that the Indians were declared to be true men possessing souls".

\section{B. The Globalization Aspect of the Sample}

Since no translation is entirely "the best or even acceptable" (Robinson 1997, p. 25), the translator cannot be certain that the adequacy of the proposed proverb equivalents. According to Catford (1965), when the lexical substitutes are unavailable in the target language, equivalence is not achieved at all. In light of Catford's remark, proverbs are idiomatic and this makes them idiosyncratic elements which are culturally bound to a specific language (Gorjian 2008, p. 1).

Mollanazar (2001) defined the proverb as "a unit of meaning in a specific context through which the speaker and hearer arrives at the same meaning" (p. 53). Translating sayings and proverbs is sometimes very difficult if not impossible. Translators in these cases have only a few options.

Beekman and Callow (1974, p. 139) suggested three ways to translate a proverb as follows:

1. The words following the proverb could be introduced as the meaning of the proverb;

2. it can be replaced with an equivalent local proverb; and

3. its non-figurative meaning could be stated straight forwardly.

Duff (1989, p. 11) cited that "idiomatic expressions are notoriously untranslatable. These include similes, metaphors, proverbs and sayings (as good as jargon, slang, and colloquialisms)." Duff also noted that if these expressions have no equivalents in TL, the translator may approach to TL equivalents as follows:

1. Literal translation,

2. original word in inverted commas,

3. close equivalents, and

4. non- idiomatic translation.

They may try to convey the meaning by explaining or interpreting, especially when the saying is too difficult to understand for a target text (TT) reader who has no or little background knowledge about the source language (SL). Here the translator preferred to translate the source text (ST) literally. With regard of media and other translations, most Iranians may know about the Indian American battle. This saying has entered to the Persian language and Iranians also say that saying when they want to refer to someone or something who/which is really not good although they use it rarely. According to Cronin (2009) translation here is of "centripetal form" which is "implying imperialism, subjection, hegemony, Westernization or Americanization".

\section{Sample from a Postcolonial Approach View}

Venuti (1995a, p. 20) "advocated foreignizing translation as a means of resisting 'ethnocentrism and racism, cultural narcissism and imperialism' and promoting 'democratic geopolitical relations" (quoted in Wang 2009, p. 203). Translator of this novel preferred foreignization once again. The literary translation of this sentence empowered the source language's (SL) culture and whether consciously or subconsciously imposes some cultural elements of dominant culture into dominated culture. This old American saying might lead to new Iranian sayings in the future.

خاطرت هت كه براى بدر ملت جهه اتفاقى افتاد؟ درخت كيلاس را با تبر قطع كرد و بعد به بدرش كفت: من نمى تو انم دروغ بكويم. كمى بعد از آن،

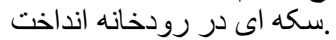

(Lolachi and Keyhan 2010, p. 126)

Remember what happened to the father of our country. He chopped down the cherry tree, and then he said to his father, 'I cannot tell a lie.' Soon thereafter, he threw the coin across the river (Auster 2006, 84).

Romanization of the Sample:

khātirat hast ki barāyi pidar-i millat chi ittifaq-i uftād? dirakht-i gīlās rā bā tabar qat' kard va ba'd bi pidarash guft: man nimītāvānam dūrūgh bigūyam: man nimītāvānam dūrūgh bigūyam. kamī ba'd az ān sikke-yī dar rūdkhānah andākht.

\section{Culture-specific Items $(s)$}

As Nord (1997) defined cultural items can be "a social phenomenon of a culture X that is regarded as relevant by the members of this culture and, when compared with a corresponding social phenomenon in a culture $\mathrm{Y}$, is found to be specific to culture X" (p. 34).

Historical events or stories can be considered of this type like George Washington's story. These kinds of stories can be found in almost all of the countries, e.g. the story of آرش كماندار in Iran. When an author refers to such historical facts 
and the text gets translated, translators may face two strategies. They can choose a foreignization strategy and remain faithful to the source text (ST) by translating the fact. They can give footnotes to help the target text reader to have a better understanding. By doing this the historical fact will become more and more global. Even if the translator does not give footnotes the fact will still become more global. The second strategy is using a very domesticated method and a translator can mention a similar fact of the target culture instead of translating the source text (ST). This can lead to a great loss in translation.

\section{E. The Globalization Aspect of the Sample}

The text is talking about the father of America. The target text reader would have probably no idea with the concept if the author would not mention George Washington's name on the following line. Although it helps to the target text reader to know that to whom it refers but the reader who does not have enough historical background about American history may still wonder why do Americans refer to George Washington as the father of their country? Interested reader with a little research can find that Washington was the first president of the America and one of the founding fathers who put in place America's governmental system. If it were not for his defeat of the British in the American Revolution, the USA would not have come into being (Wikipedia). Translation of this text is imposing dominant culture's history to the target language.

\section{F. Sample from a Postcolonial Approach View}

Source text (ST) here is referring to two stories about George Washington. An Eastern or non-American reader may probably do not know about these stories and translation of this text is imposing or from an optimist view is transferring some historical facts about the United States. Besides target text reader can find out that George Washington is known as the father of his country. Translator could not translate this part according to domestication strategy. She just could give footnotes to help the interested target text reader to know more about these two stories which she didn't find necessary to do.

....

(Lolachi and Keyhan 2010, p. 138)

....and then went off to the kitchen to fetch some beer. He returned with two bottles (Auster 2006, p. 93).

Romanization of the Sample:

... va ba'd bi āshpazkhānah raft tā nūshīdanī bīyavāvarad. du shīshah nūshabah āvard.

نوشابه هم داشت بر او اثر مى كرد

(Lolachi and Keyhan 2010, p. 142)

The beer had gone slightly to his head (Auster 2006, p. 95).

Romanization of the Sample:

nūshabah ham dāsht bar ū asar mīkard.

\section{G. Culture-specific Items $(s)$}

According to what Newmark (1988) called "material culture" food can be considered as a culture specific item, e.g. beer. Beer is an alcoholic drink, and alcoholic drinks are forbidden to be sold or used in Iran, as they are forbidden in Islam and are against Iran's Islamic rules. Translators sometimes are not allowed to translate the names of the alcoholic drinks or may prefer to don't do themselves. This act leads to a loss in translation and an unusual look of the target text (TT). For example in this sample the translator has translated beer into cola (نوشابه). As the translator translated the following sentence which is "The beer had gone slightly to his head" (Auster 2006, p. 95) into نوشابه هم داشت بر او اثر مى كرد which means the cola had gone slightly to his head, target text (TT) looks weird as everyone knows that cola is not an alcoholic drink and cannot go to one's head.

\section{H. The Globalization Aspect of the Sample}

As Cronin (2009) mentioned globalization is a "homogenization". The translation of this part did not serve as an imperialistic tool to westernize the text.

In some societies there are some cultural aspects which are stricter than the others and they do not let any foreign cultural aspect to impose itself to the target culture. For example on this text beer has been translated into نوشابه (Cola) for Iran's Islamic rules forbid trading and drinking beer in the entire country. So the translator is not allowed to translate beer into its real Persian equivalence as it may lead the Western culture to get imposed and enter to Iranian culture. Although the wise reader will know that drinking cola will not go to one's head.

Globalization did not happen here at least in an obvious way as translator just implied the original author's intention. If someone points out that globalization had happened in a hidden way, it can be claimed that it did not affect the dominated culture of Iran at least. The fact that Iranians are not allowed to use alcoholic drinks according to country's rules is so strong that neither translation nor globalization can have any influence on it.

\section{Sample from a Postcolonial Approach View}

Venuti (1995a, p. 20) advocates foreignization in translation but sometimes translators has to obey the rules of their country. In these situations domestication is the only way. The translator while translating this part of text had to obey the Islamic rules of the country and chose domestication. Sometimes domestication can be so close or even lead to 
censorship. Domestication strategy and censorship may be judged as an unfaithful translation but in some occasions they can be looked from an optimistic view as those kinds of translations can show the respect that a translator has about his/her country's values and beliefs.

زنى است كه ماسك هالووين 162 به صورت دارد.

(Lolachi and Keyhan 2010, p. 162)

There is the woman with a Halloween mask on her face. (Auster 2006, p. 108)

Romanization of the Sample:

zan-ī ast ki mask-i Hāluvīn bi ș ūrat dārad.

\section{J. Culture-specific Items $(s)$}

There are different customs and holidays in any language and culture. They can sometimes be common with other languages and cultures and sometimes can be different. Halloween is a non-Iranian culture-specific item. According to what Newmark (1988) categorized this is as because it is a "custom".

\section{K. What Is Halloween?}

Halloween, also referred to as All Halloween's Eve, falls on October 31. It is believed that on this day, ghosts, sprits and witches come out to harm people. In order to scare the evil spirits away, people place scary decorations such as black cats and skeletons, and ghosts in front of their homes. Children dressed in masks and colorful costumes go from door to door saying "trick or treat" and people give them candy, cookies, fruit or money. (Collis 2006, p. 102)

\section{The Globalization Aspect of the Sample}

Book or media translation can lead to "changes affecting culture and societies worldwide" (Cronin 2009, p. 129). Globalization here is imposing new cultural items to Iran's dominated culture. By doing so translators may lead to the entrance of the new dominant cultural items to the language.

\section{Sample from a Postcolonial Approach View}

Translation of customs, events and holidays is not usually possible through a domesticated strategy as any language and culture has its own customs, etc. so translators have to use a foreignized method and in the case of lack of equal equivalence they may even get transliterated. For translating different aspects of the source culture, the translator gave footnote to explain the situation and help the target text reader to have a better understanding, although the footnote is not detailed and gives the reader a very general overview of the custom.

يكى سينى غذا كنار تختش بود، از روى بشقاب رست بيف بخار بلند مى شد

(Lolachi and Keyhan 2010, p. 187)

There was a tray of food beside him on the floor, the dishes steaming with what looked like a roast beef dinner (Auster 2006, p. 126).

Romanization of the Sample:

yik sīn̄i ghazā kinār-i takhtash būd, az rūyi bushqāb-i rust bīf bukhār buland mīshud.

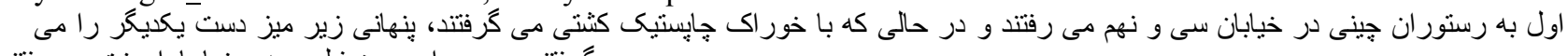

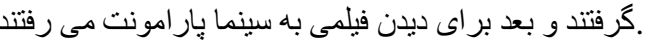

(Lolachi and Keyhan 2010, p. 201)

First the Chinese restaurant on 39th Street, where they would have wrestled with the chopsticks and held hands under the table, and then the double feature at the Paramount. (Auster 2006, p. 136)

Romanization of the Sample:

avval bi ristūrān-i Chīn̄i dar khīyābān-i sī u nuhum mīraftand va dar ḥ ālī ki bā khvurāk-i chāpistîk kushtī mīgiriftand, pinhānī zīr-i mīz dast-i yikdigar rā mīgiriftand va ba'd barāyi dīdan-i fìlmī bi sīnamā Pārāmunt mīraftand.

بقيه ى هيكلش كاملا عادى است (بالتوى توئيد خاكسترى بوشيده و دستمال كردن سرخى بسته است).

(Lolachi and Keyhan 2010, p. 243)

The rest of him is perfectly ordinary (gray tweed overcoat, red scarf wrapped around his neck) (Auster 2006, p. 164). Romanization of the Sample:

baqiyyah-yi hiykalash kāmilan 'ādī ast (pāltu-yi tu'̄̄d-i khākistari pūshidah va dastmāl garden-i surkhī bastah ast).

\section{N. Culture-specific Items $(s)$}

As Newmark (1988) categorizes from one hand, food is a "material culture" so it has been considered as a culturespecific item. From another hand also "lexical gaps are culture specific terms" (O'Donoghue 2005, p. 8).

\section{O. The Globalization Aspect of the Sample}

The two general strategies identified by Vinay and Darbelnet (2000, p. 84-93) are direct translation and oblique translation. The two strategies comprise seven procedures, of which direct translation covers three (quoted in Munday 2001, p. 55). One of those is calque. The other name of translating only the alphabet of the source word in target language is transliteration. Sometimes because of the lack of an equal equivalent word in the target language translator

؛ عيد هالويين، شب سى و يكم اكتبر ، كه كودكان در آن ماسك وحشتناك به صورت مى زنندو براى كرفتن شيرينى و يول تو جيبى به در خانه ها مى روند.Halloween. 1 
has no choice but to transliterate. This act can lead to the entrance of new words to target language, e.g. kiwi, computer, telephone, etc. But sometimes there are still equal equivalences in target language, translators still transliterate instead

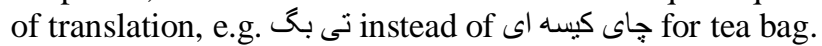

Here, there are three words which had been transliterated. First one is roast beef which could easily translated into but the translator preferred ركّت بيت بريان شده ى كاو

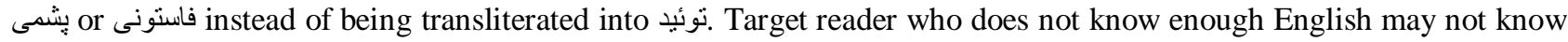
the exact meaning of the sentence. If translators keep doing so, the target language may soon face the entrance of a lot of English words into Persian language.

The second word is chopsticks. There is no good equal equivalence for chopsticks in Persian as Iranians do not use them at all. The best way here is to transliterate which will lead to the entrance of the word and its meaning to the language. Translator could help the target reader better by giving a footnote. Although there is some mistranslation here the researcher did not consider it as it would not be to the point of this study.

Globalization here is not leading to the disappearing of the dominated culture of Iran but it imposes dominant language vocabularies into the target language culture.

\section{P. Sample from a Postcolonial Approach View}

Foreignization strategy is obviously used here even in an exaggerated way. There is no reason to transliterate instead of translation while there are equal equivalences. These kind of translations impose the Western elements into the target language and they "inform and empower the colonizers" (Niranjana 1992 quoted in Wang 2009, p. 201).

\section{RESULTS}

To make a summary of the results, there were altogether 16 culture-specific items identified in the novel, The New York Trilogy that the researcher tried to analyze from a globalization aspect and also from a postcolonial view based of Venuti's domestication and foreignization strategies. The following figures illustrate the frequency of the usage of both strategies by Iranian translators in the translation of the novel.

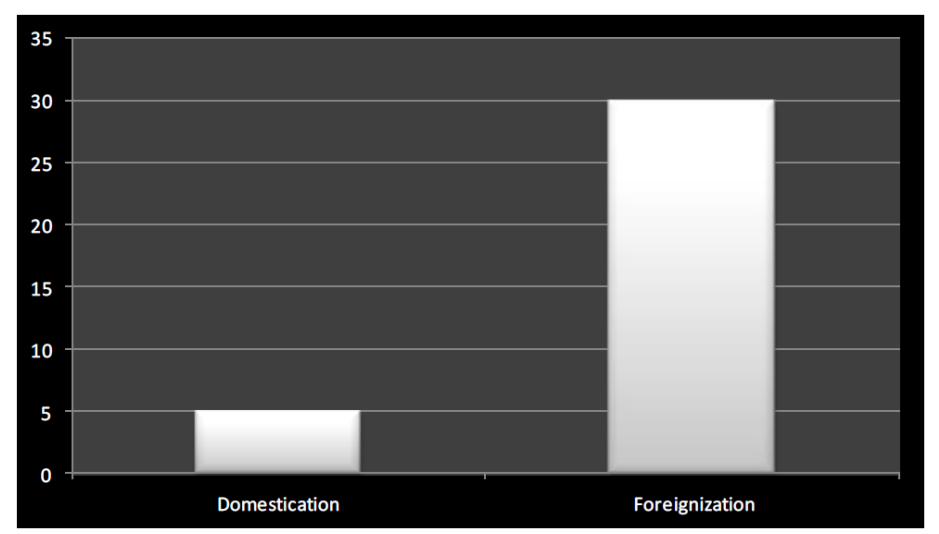

Figure 1. The Frequency of Using Domestication and Foreignization Strategy

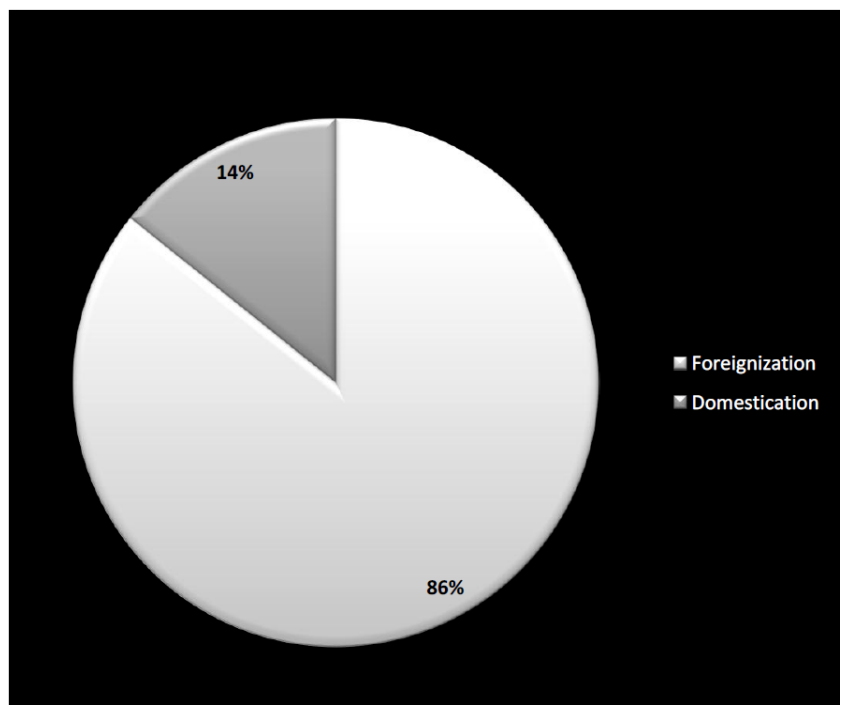

Figure 2. The Percentage of Applying Foreignization and Domestication Strategies during the Process of Translation 
As the figures above demonstrate translators used foreignization strategy preferably. "Fig. 2", demonstrates the percentage of applying each strategy which had been used during the process of translation. Foreignization strategy had been used $86 \%$ and domestication strategy had been used $14 \%$ in this study.

\section{CONCLUSION}

The present study attempted to detect what the effect of globalization on the dominated culture of Iran is. In order to achieve to this the researcher attempted to find out if Iranian translators prefer domestication strategy on translations or foreignization strategy.

Globalization is a good phenomenon from an optimistic aspect. It makes nationalities and different cultures closer to each other and helps people from all over the world to have a better and more correct attitude toward each other and helps them to have a better understanding of each other. With the help of globalization borders fade more and more on the daily life of the people and turn to something that is just clear only on the geographical maps. Globalization has a wrong aspect too and it is the way it is not equally reciprocal. Actually it is unilateral most of the time. Sometimes it seems that globalization is a tool which is serving the powerful to get more powerful and makes the weaker to become weaker. As it has been mentioned in chapter one, translation usually occurs from English and not into it. In this case globalization only or at least mostly takes place from a dominant culture, i.e. in this case English language and American culture and affects the dominated language and culture, i.e. Persian language and Iranian culture.

Foreignization in translation helps to globalization to occur from the original language to the target language. On the other hand domestication in translation keeps the cultural elements of the target language more stable. It leads to a fluent translation and perhaps translations who follow a domestication strategy may consider more successful translations because of their fluency. According to the results Iranian translators prefer foreignization strategy most of the time.

As it has been mentioned above, Iranian translators preferred foreignization strategy in most cases. It was also pointed out that foreignization strategy can lead to globalization. As analyzed in chapter four, Iranian translators can lead to the entrance of the new cultural specific items into the Persian language and Iranian culture. Those culture specific items include customs, idioms and sayings, habits, dress ups, food, work and leisure, concepts, etc.

This study has analyzed translation from a postcolonial approach. As mentioned in chapter two according to Venuti (1995a quoted in Wang 2009) "fluent, domesticating translations create the illusion of invisible translators and transparent representations, which helps to conceal their imperialistic, ethnocentric reduction of cultural difference" (pp. 201-2). With regard to this concept, this study followed domestication and foreignization strategy of Venuti in analyzing the data from a postcolonial approach.

Translators can lead to the entrance of any one of above mentioned culture-specific items from the dominant original language and culture into the dominated target language and culture, especially in the case of repetition.

\section{REFERENCES}

[1] Auster, P. (2006). The New York Trilogy (with an introduction by Luc Sante ed.). New York, New York, U.S.A.: Penguin Group.

[2] Beekman, J., \& Callow, L. (1974). Translating the word of God. USA: The Zondervan Corporation for Summer Institute of Linguistics.

[3] Catford, J. C. (1965). An essay in applied linguistics: Theory of translation. London: Oxford University Press.

[4] Collis, H. (2000). 101 American Customs. Understanding American Language and Culture Through Common Practices. Chicago: Passport Books.

[5] Cronin, M. (2003). Translation and Globalization. London and New York: Routledge.

[6] Cronin, M. (2009). Globalization. In M. Baker, \& G. Saldanha (eds.), Routledge Encyclopedia of Translation Studies (2nd edn.), 126-129. London and New York: Routledge.

[7] Duff, A. (1989). Translation. Oxford: Oxford University Press.

[8] Gentzler, E. (2003). Translation, Postcolonial Studies, and the Americas. EnterText, 2, 12-38.

[9] Goodenough, W. H. (1964). Cultural Anthropology and Linguistics. In D. Hymes (ed.), Language in Culture and Society. A Reader in Linguistics and Anthropology. New York: Harper and Row.

[10] Gorjian, B. (2008). Translating English proverbs into Persian: A case of comparative linguistics. An Article Presented in UCCTS, China.

[11] Ho, G. (2005). Globalization and Translation: Towards A Paradigm Shift in Translation Studies. A thesis submitted in partial fulfillment of the requirement for the degree of Doctor of Philosophy in Translation Studies, The University of Auckland.

[12] Keyhan, Kh. \& Lolachi, Sh. سه كانه نيويورك: شهر شيشه ای، ارواح، اتاق دربسته (2010) [The New York Trilogy: City of Glass, Ghosts, The Locked Room]. Tehran: Nashr-e Ofogh.

[13] Mollanazar, H. (2001). Principles and methodology of translation. Tehran: SAMT.

[14] Munday, J. (2001). Introducing Translation Studies: Theories and Applications. London and New York: Routledge.

[15] Newmark, P. (1988). A Textbook of Translation. New York and London: Prentice Hall.

[16] Niranjana, T. (1992). Siting Translation: History, Post-structuralism and the Post-colonial context. Berkeley: University of California Press.

[17] Nord, C. (1997). Translating as a Purpiseful Activity. Functionalist Approaches Explained. Manchester: St. Jerome. 
[18] O’Donoghue, S. (2005). Cognitive Chances in Reader-Evoked Frames: Culture-specific references in Edna O'Brien's The Country Girls and its Finnish translation. A Pro graduate Thesis in English, University of Jyväskylä, Department of Languages.

[19] Pieterse, J. (1995). Globalization as Hybridization. In M. Featherstone (Ed.), Global Modernities, 45-67. London: Sage.

[20] Robinson, D. (1997). Becoming a translator: An accelerated course. London: Routledge.

[21] Sahlins, M. (1995). Introduction. In Our Creative Diversity. o.A.d.O.: World Commission on Culture and Development.

[22] Terestyényi, E. (2011). Translating Culture-specific Items in Tourism Brochures.

[23] Venuti, L. (1992). Rethinking Translation: Discourse, Subjectivity, Ideology. London and New York: Routledge.

[24] Venuti, L. (1995). The Translator's Invisibility. London and New York: Routledge.

[25] Venuti, L. (Ed.). (2004). The Translation Studies Reader (second ed.). London and New York: Routledge.

[26] Vinay, J. P., \& Darbelnet, J. (1958/2nd edition 1977). Stylistique combarie du français de l'anglais: Méthode de traduction (2nd ed.). Paris: Didier, translated and edited by J. C. Sager, \& M. J. Hamel (1995) as Comparative Stylistics of French and English: A Methodology for Translation. Amsterdam and Philadelphia, PA: John Benjamins.

[27] Wang, H. (2009). Postcolonial Approaches. In M. Baker, \& G. Saldanha (Eds.), Routledge Encyclopedia of Translation Studies (2nd edn), 200-204. London and New York, OX, England: Routledge.

[28] Williams, J., \& Chesterman, A. (2002). The Map. A beginner's Guide to Doing Research in Translation Studies. Manchester and Northampton: St. Jerome.

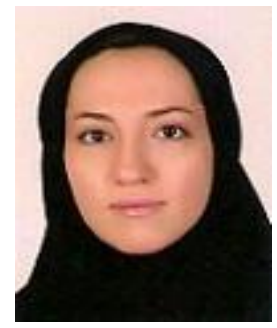

Niloufar Fallahshahrak was born in Tabriz, Iran, in 1987. She lives in Tabriz. She is an M.A. candidate of Translation Studies at East Azarbaijan Science and Research Branch, Islamic Azad University of Tabriz, Iran. She received her B.A. in English Translation and Interpretation from Islamic Azad University of Tabriz, Iran in 2010. Her main areas of interest are literary translation and cultural studies.

She was an ENGLISH INSTRUCTOR in Novin English Language Institute located in Tabriz, Iran from January 2008 until January 2009

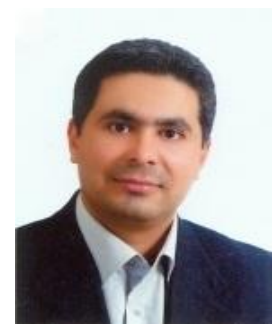

Bahloul Salmani was born in Tabriz, Iran, in 1974. He has a Ph.D in Translation Studies. He is currently an ASSISTANT PROFESSOR in the Department of English Language and Literature of Azerbaijan Shahid Madani University. 